\title{
Late Holocene fire history and charcoal decay in subtropical dry forests of Puerto Rico
}

\author{
Wei Huang ${ }^{1}$, Xianbin Liu', Grizelle González ${ }^{1}$ and Xiaoming Zou ${ }^{1,3^{*}}$ (B)
}

\begin{abstract}
Background: Fire is an important disturbance that influences species composition, community structure, and ecosystem function in forests. Disturbances such as hurricanes and landslides are critical determinants of community structure to Caribbean forests, but few studies have addressed the effect of paleofire disturbance on forests in Puerto Rico, USA. Soil charcoal is widely used to reconstruct fire history. However, the occurrence and frequency of paleofire can be underestimated due to charcoal decay.

Results: We reconstructed the fire history of subtropical dry forests of Puerto Rico based on the analysis of soil macrocharcoal numbers adjusted by the negative exponential decay function of charcoal. Twenty-one fire events occurred over the last $1300 \mathrm{yr}$ in the subtropical dry forest of northeastern Puerto Rico, and 10 fire events occurred over the last $4900 \mathrm{yr}$ in the subtropical dry forest of southeastern Puerto Rico. The average turnover time of charcoal in these subtropical dry forest soils of Puerto Rico was 1000 to $1250 \mathrm{yr}$. Soil charcoal decay leads to an underestimation of one to two undetected fire events during the Late Holocene in the subtropical dry forests of Puerto Rico. The peak of paleofire events for subtropical dry forests in northeastern and southeastern Puerto Rico was broadly similar, occurring between 500 to 1300 calibrated years before present (cal yr BP; before present is understood to mean before 1950 AD). Fire frequency of the subtropical dry forests in Puerto Rico decreased after the immigration of Europeans in the past 500 yr. The fire that occurred between 4822 and 4854 cal yr BP can be interpreted as either a natural fire or a new record of a native peoples settlement in southeastern Puerto Rico. Fire became a frequent disturbance in the subtropical dry forest of Puerto Rico after the development of cultigens by native peoples.
\end{abstract}

Conclusions: Our data suggested that fire was a frequent disturbance and human activity was likely a dominant cause of these paleofires in the subtropical dry forests of Puerto Rico.

Keywords: anthropology, charcoal decay, paleoclimate, paleofire, Puerto Rico forest, soil charcoal

\footnotetext{
*Correspondence: xzou2011@gmail.com

'Department of Environmental Sciences, College of Natural Sciences,

University of Puerto Rico, P.O. Box 70377, San Juan, PR 00936-8377, USA

${ }^{3}$ College of Biology and the Environment, Nanjing Forestry University, 159

Longpan Road, Nanjing 210037, Jiangsu, China

Full list of author information is available at the end of the article
} 


\section{Resumen}

Antecedentes: El fuego es un disturbio importante que influencia la composición de especies, la estructura de la comunidad, y el funcionamiento de los ecosistemas de bosques. Disturbios como huracanes y deslizamiento de tierras son determinantes críticos de la estructura de bosques del Caribe, aunque pocos estudios han enfocado sobre los efectos de los disturbios de los paleo-fuegos en los bosques de Puerto Rico, EEUU. Estudios sobre carbón en los suelos son ampliamente usados para reconstruir la historia de fuego. Sin embargo, la ocurrencia y frecuencia de paleo-fuegos puede ser subestimada debido al decaimiento en el contenido de carbón.

Resultados: Reconstruimos la historia de fuego de los bosques secos subtropicales de Puerto Rico basados en el análisis del número de macro carbón en los suelos ajustado por una función exponencial negativa del decaimiento del carbón. Veintiún eventos de incendio ocurrieron en los últimos 1300 años en los bosques subtropicales secos del noreste de Puerto Rico, y diez eventos de incendio en los últimos 4900 años en el bosque subtropical seco del sureste de Puerto Rico. El tiempo de recurrencia promedio del carbón en esos bosques secos de Puerto Rico fue de 1000 a 1250 años. El decaimiento del carbón lleva a la subestimación de uno a dos eventos de fuego no detectados durante el Holoceno tardío en los bosques subtropicales secos de Puerto Rico. El pico de eventos de paleo-fuegos para los bosques secos en el noreste y sureste de Puerto Rico fue considerablemente similar, ocurriendo entre 500 y 1300 años calibrados antes de ahora (cal yr BP; antes de ahora significa antes de 1950 después de Cristo). La frecuencia de fuego de los bosques subtropicales secos de Puerto Rico decreció después de la inmigración de europeos en los últimos 500 años. El fuego ocurrido entre 4822 y 4854 cal yr BP puede ser interpretado tanto como un incendio natural o como un nuevo registro del establecimiento de pueblos nativos en el sureste de Puerto Rico. El fuego se transformó en un disturbio frecuente en los bosques subtropicales secos de Puerto Rico después del desarrollo de cultivos por parte de los pueblos nativos.

Conclusiones: Nuestros datos sugieren que el fuego fue un disturbio frecuente y que las actividades humanas fueron probablemente la causa dominante de estos paleo-fuegos en los bosques subtropicales secos de Puerto Rico.

\section{Introduction}

Fire is one of the main disturbance factors affecting species distribution, succession, and evolution in many forest ecosystems (Adámek et al. 2015, Bush et al. 2015). Fire influences the distribution and occurrence of plants by favoring those with high tolerance to fire and those capable of rapid colonization on the burned site. Factors influencing forest community such as soil type, topography, species composition, and time elapsed between fire disturbances are important in determining the scenarios of successional dynamics of forest regeneration after fire (Frégeau et al. 2015).

Disturbance is regarded as a critical determinant of species composition and community structure in the forests of Puerto Rico (Waide and Lugo 1992). Research on disturbances in the forests of Puerto Rico has mostly concentrated on hurricanes and landslides (Guariguata 1990, Foster et al. 1999). Hurricane and fire disturbance share some cyclic characteristics in many tropical forests (Cochrane and Schulze 1999, Pascarella et al. 2004). The resprouting of surviving trees and the establishment and growth of seedlings and saplings of pioneers in open patches are the same important components of tropical forest recovery following both hurricane and fire disturbance (Zimmerman et al. 1994, Hjerpe et al. 2001). Frequent and possibly more intense natural fires occurred around 5200 calibrated years before present (cal yr BP, where 0 yr BP corresponds to $1950 \mathrm{AD}$ ) in a coastal region of Puerto Rico (Caffrey and Horn 2014, Rivera-Collazo et al. 2015). Regional climate issues in the pan-Caribbean area (e.g., hurricanes and the interannual changes in the position of the Intertropical Convergence Zone; Barry and Chorley 2010) were reported to induce paleofire in Dominica and Cuba (Crausbay et al. 2015, Peros et al. 2015). Synchrony of fire is a characteristic of climate-driven burning (Caffrey and Horn 2014). Thus, frequent paleofires might also have occurred in Puerto Rico during the Late Holocene. However, studies of paleofire in Puerto Rico are surprisingly rare.

Soil macrocharcoal $(>2 \mathrm{~mm}$ ) is widely used to reconstruct fire history in situ and to compare regional fire histories because it is not transported over long distances (McMichael et al. 2012, Hubau et al. 2015). But random samples of soil charcoal do not guarantee that all fires are detected, because 1) some soil charcoal particles can be missed during random sampling of soil, and 2) charcoal may disappear or reduce in size due to its decay (Frégeau et al. 2015, Payette et al. 2017). Therefore, an increasing number of studies has constructed accumulation curves to estimate the actual number of local fires (Payette et al. 2012, Payette et al. 2017). However, few studies have 
considered a decrease in charcoal size over time caused by charcoal decay and the burning of charcoal during subsequent fires. Frégeau et al. (2015) used a negative exponential function to evaluate charcoal decay, but his estimation was based on the assumption that the numbers of charcoal fragments originating from fires were invariant over every 200-year period. This assumption is likely wrong, because charcoal abundance is subject to changes due to fire intensity and frequency (Tovar et al. 2014, Inoue et al. 2016), which can differ with climatic conditions.

In order to address the gaps in paleofire knowledge in Puerto Rico, we conducted this study to: 1) reconstruct fire history in subtropical dry forests of Puerto Rico through radiocarbon dating of soil charcoal fragments; 2) estimate charcoal decay rates based on maximum charcoal sizes within each time interval; 3) estimate the number of missing fire events due to charcoal decay; and 4) infer the effect of paleoclimate on paleofire in the subtropical dry forests of Puerto Rico by pairing charcoal ${ }^{13} \mathrm{C}$ discrimination $\left(\Delta^{13} \mathrm{C}\right)$ with contemporary plant $\Delta{ }^{13} \mathrm{C}$ values.

\section{Methods}

\section{Study area}

The study area was located in eastern Puerto Rico, USA (Fig. 1). Nine sites were sampled and partitioned into two forest assemblages representing the subtropical dry forests in Puerto Rico.

The first forest assemblage was referred to as the northeastern subtropical dry forest (Ewel and Whitmore 1973) and included three sites: Ceiba I, Ceiba II, and Las Cabezas, between $18.22^{\circ}$ and $18.38^{\circ} \mathrm{N}$, and $65.60^{\circ}$ and $65.67^{\circ} \mathrm{W}$ (Fig. 1), which were situated between sea level and up to nearly $100 \mathrm{~m}$ in elevation, with a $15.2^{\circ}$ average slope inclination (Gould et al. 2006). The average annual temperature was $25.7{ }^{\circ} \mathrm{C}$, and the average annual precipitation was $1416 \mathrm{~mm}$. The soils were generally composed of Alfisol and Hapustalfs (Ping et al. 2013), had an average depth of $0.38 \mathrm{~m}$ and a $\mathrm{pH}$ of 6.51 . The parent material of this soil is Colluvium and Andesitic residuum (Ping et al. 2013). Most abundant trees included Bucida buceras L., Guapira fragrans (Dum. Cours.) Little, Bourreria succulent Jacq., and Gymnanthes lucida Sw.; the shrub layer was dominated by

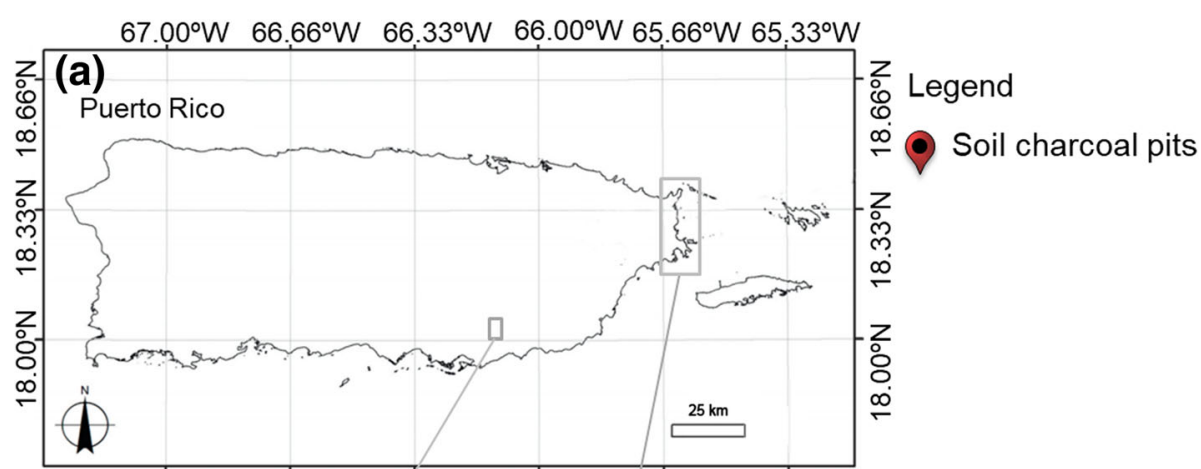

$67.00^{\circ} \mathrm{W} 66.66^{\circ} \mathrm{W} 66.33^{\circ} \mathrm{W} 66.00^{\circ} \mathrm{W} 65.66^{\circ} \mathrm{W} 65.33^{\circ} \mathrm{W}$
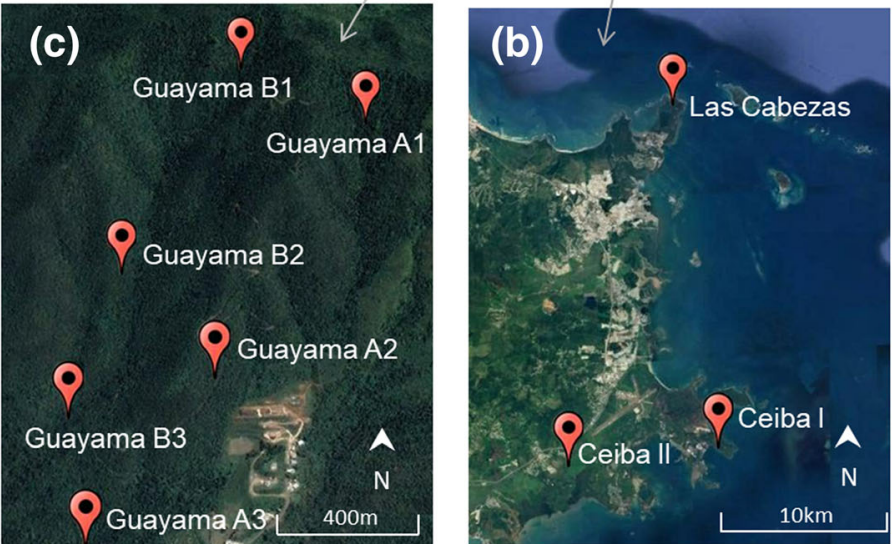

Fig. 1 Location of the study area and sites in the subtropical dry forests of Puerto Rico, USA. a Map of Puerto Rico; $\mathbf{b}$ soil charcoal pits in northeastern dry forest; c soil charcoal pits in southeastern subtropical dry forest. Charcoal was sampled in December 2015 in the northeastern subtropical dry forest, and in December 2014 in the southeastern subtropical dry forest 
Triphasia trifolia (Burm. f.) P. Wilson, Chamaesyce articulate (Burm.) Britton, Lantana camara L., and Argythamnia stahlii Urb.; and several species of lichens included Macfadyena unguis-cati (L.) A.H. Gentry, Tragia volubilis L., and Serjania polyphylla (L.) Radlk. (Gould et al. 2006).

The second forest assemblage was referred to as the southeastern subtropical dry forest (Ewel and Whitmore 1973) and included six sites in the USDA Forest Service, Institute of Tropical Forestry's Guayama Research Area, between $18.04^{\circ}$ and $18.05^{\circ} \mathrm{N}$, and $66.16^{\circ}$ and $66.17^{\circ} \mathrm{W}$ (Fig. 1). These sites were located between $270 \mathrm{~m}$ and up to nearly $640 \mathrm{~m}$ in elevation, with $28.2^{\circ}$ average slope inclination. The average annual temperature was $22.72{ }^{\circ} \mathrm{C}$, and the average annual precipitation was $1693.18 \mathrm{~mm}$. The soils were generally composed of shallow Typic Haplustalfs (Muñoz et al. 2017), with an average depth of $1.1 \mathrm{~m}$ and soil pH of 5.32. The parent material of this soil is semiconsolidated volcanic rocket (USDA Soil Conservation Service 1977). The most abundant tree species in this subtropical dry forest included Bucida buceras, Casearia guianensis (Aubl.) Urb., Pictetia aculeate (Vahl) Urb., Nectandra coriacea (Sw.) Griseb., Andira inermis (W. Wright) Kunth ex DC., Guapira fragrans (Dum. Cours.) Little, Randia aculeata L., Zanthoxylum monophyllum (Lam.) P. Wilson, Eugenia foetida Pers., and Leucaena leucocephala (Lam.) de Wit.

\section{Soil sampling and charcoal extraction}

A square plot $(10 \mathrm{~m} \times 10 \mathrm{~m})$ was positioned at each site. At each plot, a $20 \mathrm{~cm} \times 20 \mathrm{~cm}$ area of surface organic matter was removed to expose the mineral soil. Soils were sampled from surface to parent material, at $20 \mathrm{~cm}$ intervals per sample layer, to maintain a fine vertical resolution of the extracted charcoal assemblages. In the laboratory, the mineral soils were suspended in $10 \%$ potassium hydroxide $(\mathrm{KOH})$ solution for at least $24 \mathrm{~h}$ in order to disperse soil aggregates (Inoue et al. 2016). The soils were wet-sieved using superimposed sieves of $5 \mathrm{~mm}$ and $2 \mathrm{~mm}$. The macrocharcoal fragments were extracted from the sieves, washed, and weighed.

\section{Wood litterfall collection and branch sampling}

Within each plot in the northeastern subtropical dry forest, we randomly installed three baskets of $0.25 \mathrm{~m}^{2}$ at $1 \mathrm{~m}$ above ground level. The wood collected in the baskets from each plot was combined into a single sample. Wood was collected every month from January to December 2015.

Five dominant species (Andira inermis, Zanthoxylum monophyllum, Guapira fragrans, Casearia guianensis and Nectandra coriacea) and two other species (Ardisia obovata Desv. ex Ham. and Ficus citrifolia Mill.) in the southeastern subtropical dry forest were selected for wood sampling. Three plants per species were randomly chosen in the southeastern subtropical dry forest. From 10 to 20 Dec 2015, 10 first-year branches per plant were collected. Wood litterfall and branch samples were $65^{\circ} \mathrm{C}$ oven dried, and ground through a $1 \mathrm{~mm}$ sieve.

\section{Radiocarbon dating}

Before radiocarbon dating, charcoal samples were cleaned with $1 \mathrm{M}$ hydrochloric acid $(\mathrm{HCl})$ and $1 \mathrm{M}$ sodium hydroxide $(\mathrm{NaOH})$ to remove any adsorbed dissolved organic matter. All samples were dried prior to analysis. The radiocarbon ages of 20 charcoal samples from the northeastern subtropical dry forest were determined by AMS (Accelerator Mass Spectrometry) at the Earth System Science Department, University of California, Irvine, USA; and the radiocarbon ages of 58 charcoal samples from the southeastern subtropical dry forest were determined by AMS at the Lawrence Livermore National Laboratory, California, USA.

The calibrated age of charcoal was obtained using the Calib 704 software (Queen's University Belfast, Belfast, Northern Ireland, United Kingdom). The determination of the calibrated age of each radiocarbon date was based on the weighted average of the highest probability distribution within the $2 \sigma$ ranges of the starting and ending calendar dates. For each forest assemblage, all of the calibrated radiocarbon dates were pooled in a cumulative probability analysis using the sum probabilities option in Calib 704 to plot the probability that a given event occurred at a particular time to visualize the fire chronology on the Holocene temporal scale. All carbon-14 $\left({ }^{14} \mathrm{C}\right)$ dates were presented in cal yr BP (Frégeau et al. 2015).

\section{Estimation of charcoal decay rate}

The decrease of charcoal weight with time was caused by charcoal decay and burning of charcoal during subsequent fires. For charcoal found in mineral soils below the surface layer, this decrease of charcoal weight over time was most likely due to charcoal decay, not by fire. Soil charcoal decay is a function of microbial activity wherein soil charcoal is colonized and consumed by soil microbial communities (Moskal-del Hoyo et al. 2010, Tilston et al. 2016). The decay curve of soil charcoal over time is best described as an exponential function. We proposed a novel approach to estimate the charcoal decay rate over time by assuming that the maximum initial size of charcoal that gets into mineral soil in each time interval remains invariant over a 1000 -year period. Soil environment for charcoal deposition, such as pore size, drying-rewetting cycles, soil erosion, and burial rates, should be similar over a 1000-year period because soil development is extremely slow and most residential soils are aged for millions of years in the tropics (Birkeland et al. 1992). Thus, we have: 


$$
Y=Y_{0}\left(e^{-\mathrm{bx}}\right)
$$

where $Y$ corresponds to the maximum weight of charcoal at each age class, $Y_{0}$ is the maximum weight of charcoal in mineral soil at age zero, $b$ is the decay rate of charcoal (and its inverse value is the average turnover time of charcoal), and $x$ is the calibrated age of charcoal. We used a time interval of $200 \mathrm{yr}$ to identify charcoal with the maximum weight in each age class for the northeastern dry forest, and a time interval of $1000 \mathrm{yr}$ for the southeastern dry forest, ensuring a minimum number of 5 age classes with charcoal presence. We counted the number of dated charcoal samples within each age class and selected two charcoal samples with maximum weight from each age class. We then obtained charcoal decay rate $b$ using linear regression after natural logarithm transformation for both the northeastern dry forest $\left(b_{1}\right)$ and the southeastern dry forest $\left(b_{2}\right)$.

\section{Estimation of charcoal abundance}

The minimum detectable weight was $1.4 \mathrm{mg}$ for analysis at the Earth System Science Department, University of California Irvine; and was $3.5 \mathrm{mg}$ at the Lawrence Livermore National Laboratory. Thus, the number of charcoal particles as a function of time was likely underestimated because there were charcoal particles $<1.4 \mathrm{mg}$ that were $\geq 1.4 \mathrm{mg}$ at their initial weight in the northeastern subtropical dry forest, and $<3.5 \mathrm{mg}$ that were $\geq 3.5 \mathrm{mg}$ at their initial weight in the southeastern subtropical dry forest. To estimate real charcoal abundance as a function of time, we first employed Eq. (1) to estimate the initial weight of charcoal particles that were heavier than $1.4 \mathrm{mg}$ at the time of sampling in the northeastern subtropical dry forest and heavier than $3.5 \mathrm{mg}$ at the time of sampling in the southeastern subtropical dry forest.

The initial weight of the charcoal pieces $\left(Y_{01}\right)$ that were older than $200 \mathrm{yr}$ and heavier than $1.4 \mathrm{mg}$ in the northeastern subtropical dry forest was estimated through the equation:

$$
Y_{01}=\frac{1.4}{e^{-\mathrm{b}_{1}(\mathrm{x}-200)}},
$$

where $b_{1}$ corresponds to the decay rate of charcoal in the northeastern dry forest, and is the dated charcoal age.

The initial weight of the charcoal pieces $\left(Y_{02}\right)$ that were older than $1000 \mathrm{yr}$ and heavier than $3.5 \mathrm{mg}$ in the southeastern subtropical dry forest was calculated using the following equation:

$$
Y_{02}=\frac{3.5}{e^{-\mathrm{b}_{2}(\mathrm{x}-1000)}},
$$

where $b_{2}$ corresponds to the decay rate of charcoal in the southeastern dry forest, and $x$ is the dated charcoal age.

We then assumed that the abundance-size distribution of original charcoal (before decay occurs) in mineral soils in each age class remains invariant because depositional environments of soil charcoal are unlikely to change much over the course of soil development within multiple millennium years in a residential soil. Thus, the number of undetected charcoal particles $\left(n_{\mathrm{ud} 1}\right)$ that were initially heavier than $1.4 \mathrm{mg}$ and became lighter than $1.4 \mathrm{mg}$ due to charcoal decay in the northeastern dry forest were estimated using the equation:

$$
\frac{n_{\mathrm{ud} 1}}{n_{\mathrm{d} 1}}=\frac{n_{<\mathrm{Y}_{01}}}{n_{>\mathrm{Y}_{01}}},
$$

where $n_{\mathrm{d} 1}$ corresponds to the number of charcoal particles that were heavier than $1.4 \mathrm{mg}$ at the time of sampling in each age class $>200 \mathrm{yr}$ in the northeastern dry forest; $n_{<\mathrm{YO} 1}$ is the number of charcoal particles that were lighter than $Y_{01}$ but heavier than $1.4 \mathrm{mg}$ at the time of sampling in the $200 \mathrm{yr}$ age class; and $n_{>\mathrm{Y} 01}$ is the number of charcoal particles that were heavier than $Y_{01}$ at the time of sampling in the $200 \mathrm{yr}$ age class. The sum of $n_{\mathrm{ud} 1}$ and $n_{\mathrm{d} 1}$ is the number of corrected charcoal particles in each age class $>200 \mathrm{yr}$ in the northeastern dry forest.

Similarly, the number of undetected charcoal particles $\left(n_{\mathrm{ud} 2}\right)$ as a function of $1000 \mathrm{yr}$ age interval in the southeastern subtropical dry forest was estimated using the equation:

$$
\frac{n_{\mathrm{ud} 2}}{n_{\mathrm{d} 2}}=\frac{n_{<\mathrm{Y}_{02}}}{n_{>\mathrm{Y}_{02}}},
$$

where $n_{\mathrm{d} 2}$ corresponds to the number of charcoal particles that were heavier than $3.5 \mathrm{mg}$ at the time of sampling in each age class $>1000 \mathrm{yr}$ in the southeastern dry forest; $n_{<\mathrm{Y} 02}$ is the number of charcoal particles that were lighter than $Y_{02}$ but heavier than $3.5 \mathrm{mg}$ at the time of sampling in the $1000 \mathrm{yr}$ age class; and $n_{>\mathrm{YO} 2}$ is the number of charcoal particles that were heavier than $Y_{02}$ at the time of sampling in the $1000 \mathrm{yr}$ age class. The sum of $n_{\mathrm{ud} 2}$ and $n_{\mathrm{d} 2}$ is the number of corrected charcoal particles in each age class $>1000 \mathrm{yr}$ in the southeastern dry forest.

\section{Reconstruction of paleofire history}

The random sampling of charcoal does not necessarily assure that all fires will be detected (Frégeau et al. 2015). Therefore, we used EstimateS 9 software (Colwell and Elsensohn 2014) to calculate the estimated fire events 
based on the observed or corrected charcoal particles. The number of randomizations was set to 100 in the Diversity Settings screen of EstimateS 9. This type of analysis has been used to determine an expected number of species in pooled samples, given the reference sample. The accumulation curves were created according to the relationship between the observed or corrected fire events and dated or corrected charcoal particles. When the curve forms an asymptote, it suggests that most of the fires that occurred at the site have been theoretically estimated. An index was produced based on a nonlinear regression of the mean number of fires detected in relation to the number of dated or corrected charcoal pieces using the following equation:

$$
F(n)=F(\max )\left(1-e^{\mathrm{kn}}\right),
$$

where $F(n)$ corresponds to the number of fires observed or corrected, $n$ is the number of charcoal pieces dated or corrected, $F(\max )$ is considered here as an estimator of the actual number of fires, and $k$ is the constant controlling the shape of the curve (Fregeau et al. 2015). The $F(\max )$ index and the constant $k$ were calculated using the equation of exponential regression in Sigmaplot 14.0 software (Systat Software Inc., San Jose, California, USA). The mean fire interval (I), that is, the average in calibrated years of all the fire intervals, was calculated for each site:

$$
I=\frac{P}{n_{\mathrm{f}}-1},
$$

where $P$ corresponds to the fire period defined here as the time elapsed between the youngest and oldest fires and $n_{\mathrm{f}}$ is the number of fires.

\section{Stable carbon isotope analysis}

The ground samples of wood litterfall, live branches, and charcoal were sent to Michigan Technological University's Forest Ecology Stable Isotope Laboratory, Houghton, USA, for the analyses of carbon isotope composition $\left(\delta^{13} C\right)$ values using a Costech Elemental Combustion System 4010 (Costech Analytical Technologies Inc., Valencia, California, USA) connected to a continuous flow isotope ratio mass spectrometer. $\delta^{13} \mathrm{C}$ values were reported in reference to the international Pee Dee belemnite standard (Slater et al. 2001). The $\Delta^{13} \mathrm{C}$ values of charcoal, wood litterfall, and live branches were calculated through the equation:

$$
\Delta^{13} C=\frac{\delta^{13} C_{\text {air }}-\delta^{13} C_{\text {plant }}}{1+\frac{\delta^{13} C_{\text {plant }}}{1000}},
$$

where $\delta^{13} \mathrm{C}_{\text {plant }}$ is the isotopic value of the wood litterfall, live branches, or charcoal; and $\delta^{13} C_{\text {air }}$ is the isotopic value of the atmospheric $\mathrm{CO}_{2}$ in a specific time period corresponding to a smoothed $\delta^{13} \mathrm{C}$ curve of atmospheric carbon dioxide $\left(\mathrm{CO}_{2}\right)$ from $16100 \mathrm{BC}$ to the present (available at http://web.udl.es/usuaris/x3845331/ AIRCO2_LOESS.xls).

There are two stable carbon isotopes in the air: ${ }^{12} \mathrm{C}$ (carbon-12) and ${ }^{13} \mathrm{C}$. During photosynthesis, plants preferentially take in ${ }^{12} \mathrm{C}$ instead of ${ }^{13} \mathrm{C}$ (i.e., discrimination of the heavy isotope in favor of the lighter one; Fiorentino et al. 2014). In $C_{3}$ plants under optimal conditions, the stomata are fully open and the flow of $\mathrm{CO}_{2}$ inside the intercellular spaces of the leaf is not limited, leading to discrimination, and thus low $\delta^{13} \mathrm{C}$ and high $\Delta^{13} \mathrm{C}$ (Fiorentino et al. 2014). Under environmental stress (e.g., drought), plants typically defend against water stress through stomatal closure, increasing water use efficiency and $\delta^{13} \mathrm{C}$, consequently decreasing $\Delta^{13} \mathrm{C}$ in $\mathrm{C}_{3}$ plants (Fiorentino et al. 2014). This is the basis for the extensively reported relationships between plant $\Delta^{13} \mathrm{C}$ and environmental variables. In many environmental studies, it is assumed that carbon isotope ratios derived from naturally occurring and anthropogenic charcoal are a direct representation of the isotopic values of the wood tissues from which they were formed, and hence a record of environmental and climatic signals (Hall et al. 2008). $\mathrm{C}_{4}$ plants are not robust enough to be easily applicable to archaeobotanical remains (Tieszen and Fagre 1993). So, for the northeastern subtropical dry forest, the annual mean $\Delta^{13} \mathrm{C}$ of wood litterfall of 2015 was compared with charcoal $\Delta^{13} \mathrm{C}$ to infer paleoclimate. For the southeastern subtropical dry forest, the $\Delta^{13} \mathrm{C}$ of the first-year live branches of 2015 was compared with charcoal $\Delta^{13} \mathrm{C}$ to deduce paleoclimate. The year 2015 was an extreme drought year in Puerto Rico (Mote et al. 2017).

\section{Results}

\section{Charcoal abundance and decay}

In the northeastern subtropical dry forest, a total of 31 (mean of 10.33 per site) charcoal fragments were recovered (Table 1). Among all charcoal samples collected, $87.10 \%$ of all charcoal fragments were $>1.4 \mathrm{mg}$. Around $80 \%$ of charcoal samples were recovered from 0 to $20 \mathrm{~cm}$ deep in the soil (Table 2). The oldest charcoal sample was dated at 1221 to $1256 \mathrm{cal} \mathrm{yr} \mathrm{BP;} \mathrm{the} \mathrm{youngest} \mathrm{charcoal}$ sample was dated at 70 to $117 \mathrm{cal} \mathrm{yr} \mathrm{BP,} \mathrm{but} \mathrm{no} \mathrm{charcoal}$ was dated between 307 and $558 \mathrm{cal} \mathrm{yr} \mathrm{BP} \mathrm{(Fig.} \mathrm{2,}$ Additional file 1). The number of charcoal fragments increased progressively towards present time. Eighty percent of the charcoal fragments were younger than 1000 cal yr BP (Fig. 2, Additional file 1).

In the southeastern subtropical dry forest, a total of 1734 (mean of 289 per site) charcoal fragments were 
Table 1 Parameters of fire histories in subtropical dry forest of Puerto Rico, USA. Charcoal was sampled in December 2015 in the northeastern subtropical dry forest, and in December 2014 in the southeastern subtropical dry forest. The radiocarbon ages of 20 charcoal samples from the northeastern subtropical dry forest were determined by AMS (Accelerator Mass Spectrometry) at the Earth System Science Department, University of California, Irvine; and the radiocarbon ages of 58 charcoal samples from the southeastern subtropical dry forest were determined by AMS at the Lawrence Livermore National Lab

\begin{tabular}{|c|c|c|c|c|c|c|}
\hline \multirow[t]{2}{*}{ Forest type } & \multirow{2}{*}{$\begin{array}{l}\text { Charcoal } \\
\text { samples (n) }\end{array}$} & \multirow{2}{*}{$\begin{array}{l}{ }^{14} \mathrm{C} \text { dated } \\
\text { samples }(n)\end{array}$} & \multirow{2}{*}{$\begin{array}{l}\text { Fire period } \\
\text { (cal. yr BP) }\end{array}$} & \multirow{2}{*}{$\begin{array}{l}\text { Detected } \\
\text { fire events ( } n \text { ) }\end{array}$} & \multicolumn{2}{|c|}{ Estimated fire events $(n)$} \\
\hline & & & & & $\begin{array}{l}\text { Before correction } \\
\text { for charcoal decay }\end{array}$ & $\begin{array}{l}\text { After correction } \\
\text { for charcoal decay }\end{array}$ \\
\hline Northeastern subtropical dry & 31 & 20 & -2 to 1261 & 17 & 19 & 21 \\
\hline Southeastern subtropical dry & 1734 & 58 & 1 to 4858 & 9 & 9 & 10 \\
\hline
\end{tabular}

recovered (Table 1). The majority of charcoal fragments were found in the upper $40 \mathrm{~cm}$ of soil, especially in the 20 to $40 \mathrm{~cm}$ depth (Table 2). In all, $95.80 \%$ of all charcoal fragments were $>3.5 \mathrm{mg}$. The oldest charcoal was dated at 4806 to $4867 \mathrm{cal} \mathrm{yr} \mathrm{BP}$, and the youngest charcoal dated at 32 to $83 \mathrm{cal}$ yr BP, but no charcoal was dated between 2762 and $4807 \mathrm{cal}$ yr BP or between 1387 and $2359 \mathrm{cal}$ yr BP (Fig. 2, Additional file 1). The number of charcoal fragments increased progressively towards present time. In all, $62.07 \%$ of the charcoal fragments were younger than $1000 \mathrm{cal}$ yr BP (Fig. 2, Additional file 1).

The mean decay rate of charcoal was $0.0010 \mathrm{yr}^{-1}$ in the northeastern subtropical dry forest, and $0.0008 \mathrm{yr}^{-1}$ in the southeastern subtropical dry forest (Fig. 3). The mean turnover times of charcoal in the northeastern and southeastern subtropical dry forest were 1000 and $1250 \mathrm{yr}$, respectively. In the northeastern subtropical dry forest, there were three unaccounted charcoal samples that were lighter than $1.4 \mathrm{mg}$ at the time of sampling but were heavier than $1.4 \mathrm{mg}$ at the time of deposition during 1000 to $1200 \mathrm{cal}$ yr BP, and one unaccounted charcoal sample during 1200 to $1400 \mathrm{cal} \mathrm{yr} \mathrm{BP.} \mathrm{In} \mathrm{the} \mathrm{southeastern} \mathrm{subtropical}$ dry forest, there were six unaccounted charcoal samples that were lighter than $3.5 \mathrm{mg}$ at the time of sampling but were heavier than $3.5 \mathrm{mg}$ at the time of deposition between 2000 and $3000 \mathrm{cal}$ yr BP, five unaccounted charcoal samples during 3000 to $4000 \mathrm{cal} \mathrm{yr} \mathrm{BP}$, and 10 unaccounted charcoal samples in 4000 to $5000 \mathrm{cal}$ yr BP (Fig. 4).

\section{Paleofire history}

Before correction for charcoal decay, the dated charcoal revealed that the fire regime of the northeastern subtropical forest corresponded to 17 detected fires and 19 estimated fires over the last $1300 \mathrm{yr}$ (Fig. 5a, Table 1). In all, 76\% detected fires (13 fires) in the northeastern subtropical dry forest occurred between 559 and $1261 \mathrm{cal} \mathrm{yr}$ BP, with fire interval averaged $59 \mathrm{yr}$ during this period (Fig. 2a). There was a fire-free interval between 306 and $558 \mathrm{cal} \mathrm{yr} \mathrm{BP}$ in the northeastern subtropical dry forest (Fig. 2a). In the past $300 \mathrm{yr}$, there were fewer fires (4 fires) detected in the northeastern subtropical dry forest, with a longer fire interval (103 yr, Fig. 2a).

Over the last $5000 \mathrm{yr}$, fewer fires were recorded in the southeastern than in the northeastern subtropical dry forest. Before correction for charcoal decay, the dated charcoal revealed that the fire regime of the southeastern subtropical forest corresponded to nine detected fires and nine estimated fires (Fig. 5c, Table 1). Only one fire occurred between 4822 and $4852 \mathrm{cal} \mathrm{yr} \mathrm{BP}$ and between 2717 and $2753 \mathrm{cal}$ yr BP

Table 2 Depth distribution of charcoal in subtropical dry forest of Puerto Rico, USA, along the soil profile. Charcoal was sampled in December 2015 in the northeastern subtropical dry forest, and in December 2014 in the southeastern subtropical dry forest

\begin{tabular}{|c|c|c|c|}
\hline Forest type & Soil depth (cm) & Charcoal mass (mg) & Charcoal particles $(n)$ \\
\hline \multirow[t]{2}{*}{ Northeastern subtropical dry forest } & 0 to 20 & 149.8 & 24 \\
\hline & 20 to 40 & 27.4 & 7 \\
\hline \multirow[t]{7}{*}{ Southeastern subtropical dry forest } & 0 to 20 & 1102.2 & 467 \\
\hline & 20 to 40 & 4451.3 & 1195 \\
\hline & 40 to 60 & 41.3 & 14 \\
\hline & 60 to 80 & 117.5 & 16 \\
\hline & 80 to 100 & 137.7 & 33 \\
\hline & 100 to 120 & 4.9 & 5 \\
\hline & 120 to 140 & 8.3 & 4 \\
\hline
\end{tabular}



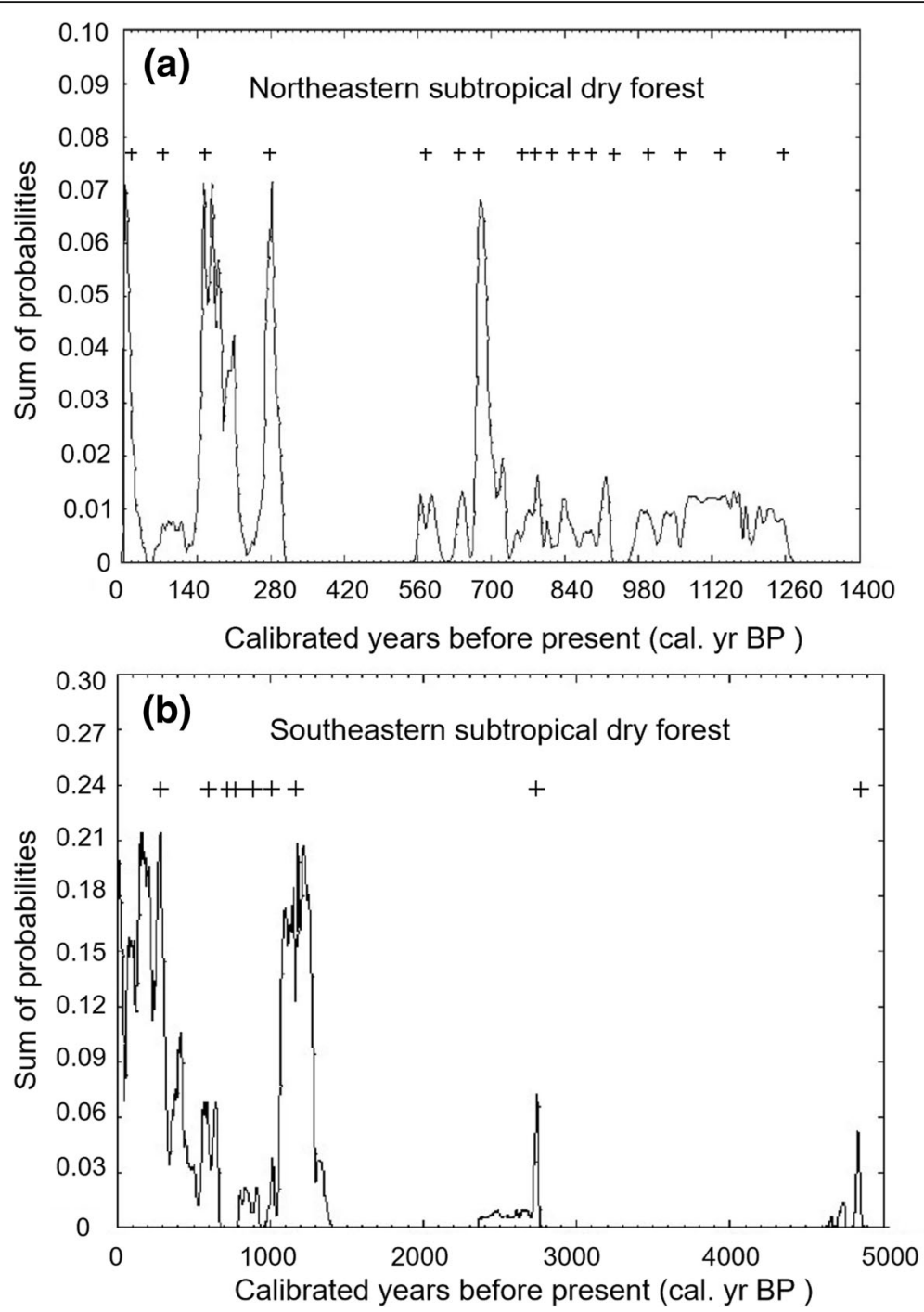

Fig. 2 Distribution of the cumulated probability of calibrated ${ }^{14} \mathrm{C}$ dates of charcoal in (a) northeastern and (b) southeastern subtropical dry forests in Puerto Rico, USA. Charcoal was sampled in December 2015 in the northeastern subtropical dry forest, and in December 2014 in the southeastern subtropical dry forest. A cross (+) indicates the occurrence of a fire event. The radiocarbon ages of 20 charcoal samples from the northeastern subtropical dry forest were determined by AMS (Accelerator Mass Spectrometry) in August and November 2016 at the Earth System Science Department, University of California, Irvine, USA; and the radiocarbon ages of 58 charcoal samples from the southeastern subtropical dry forest were determined by AMS in July and August 2015 at the Lawrence Livermore National Laboratory, California, USA. The calibrated age of charcoal was obtained using the Calib 704 software. For each forest assemblage, all of the calibrated radiocarbon dates were pooled in a cumulative probability analysis using the sum probabilities option in Calib 704 to plot the probability that a given event occurred at a particular time to visualize the fire chronology on the Holocene temporal scale

(Fig. 2b). Similar to the northeastern subtropical dry forest, $66.66 \%$ of the detected fires (6 fires) in the southeastern subtropical dry forest occurred between 539 and $1358 \mathrm{cal} \mathrm{yr} \mathrm{BP}$, and the fire interval of this period was $164 \mathrm{yr}$ (Fig. 2b). In the last $521 \mathrm{yr}$, there was only one fire detected in the southeastern subtropical dry forest (Fig. 2b).

With the addition of four undetected charcoal samples after corrections for charcoal decay, the estimated fire events increased from 19 to 21 over the past $1300 \mathrm{yr}$ in the northeastern subtropical dry forest
(Fig. 5b, Table 1). The additional two fire events should have occurred between 1000 and $1400 \mathrm{cal}$ yr $\mathrm{BP}$, which led to the decrease in the fire interval between 559 and $1261 \mathrm{cal} \mathrm{yr} \mathrm{BP} \mathrm{from} 59 \mathrm{yr}$ to $47 \mathrm{yr}$ in the northeastern subtropical dry forest. With the addition of 21 undetected charcoal samples after corrections for charcoal decay, the estimated fire events increased from 9 to 10 in the southeastern subtropical dry forest (Fig. 5d, Table 1). This one additional fire event should have occurred between 1000 and $5000 \mathrm{cal}$ yr BP, which did not change the fire interval 


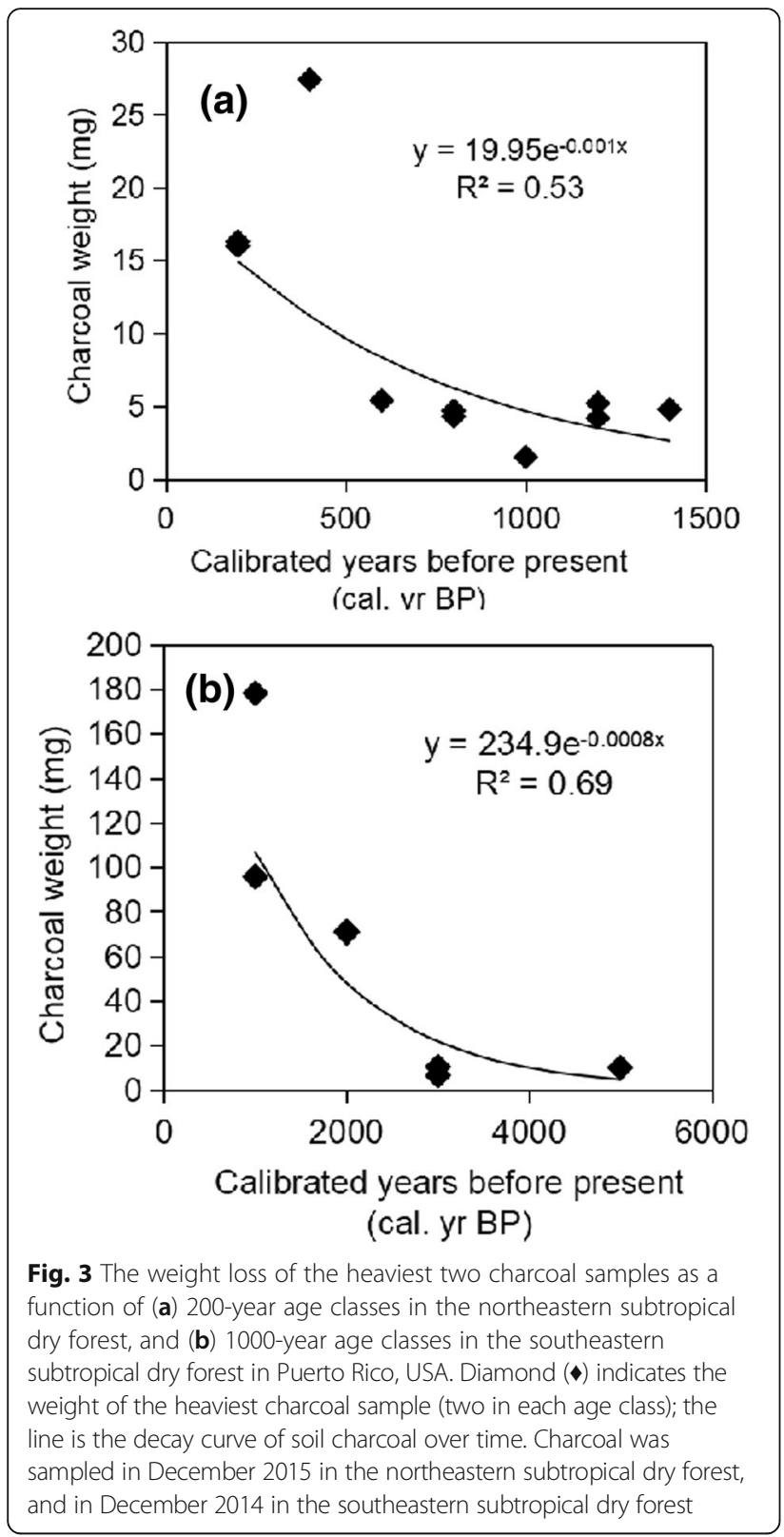

during 539 to $1358 \mathrm{cal}$ yr BP in the southeastern subtropical dry forest.

\section{Stable carbon isotope in plant wood tissues and charcoal}

We did not separate taxa attribution for the charcoal in this analysis. The $\Delta{ }^{13} \mathrm{C}$ value of charcoal from the northeastern subtropical dry forest ranged from $17.36 \%$ to $22.28 \%$ and showed a decreasing trend over last $1300 \mathrm{yr}$ (Fig. 6a). The $\Delta^{13} \mathrm{C}$ value of wood deposited in the baskets from 2015 fell right near the middle of charcoal $\Delta^{13} \mathrm{C}$ range. The ${ }^{13} \mathrm{C}$ value of charcoal from the southeastern subtropical dry forest varied from $17.70 \%$ to $26.35 \%$, and can be divided to two subsequent phases (Fig. 6b). From 800 to 5000 cal yr BP, 95\% of charcoal

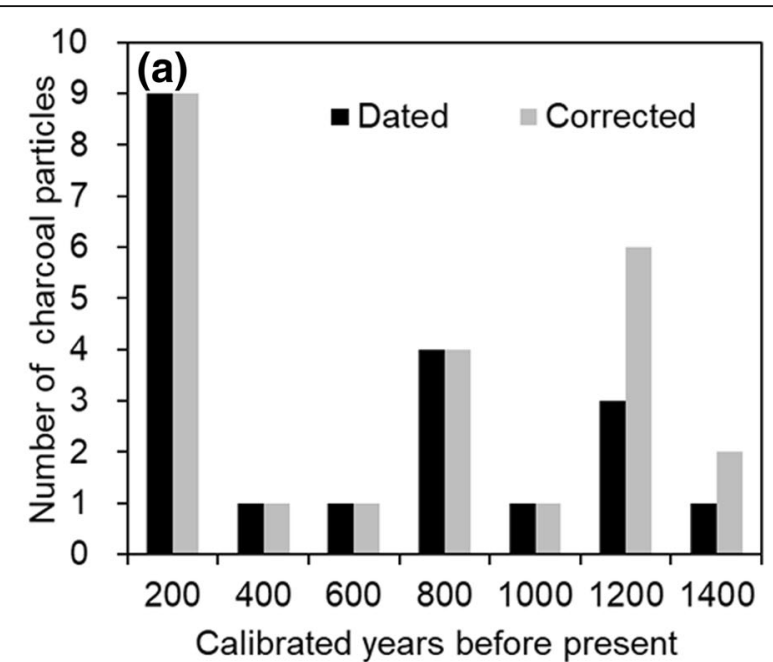

(cal. yr BP)

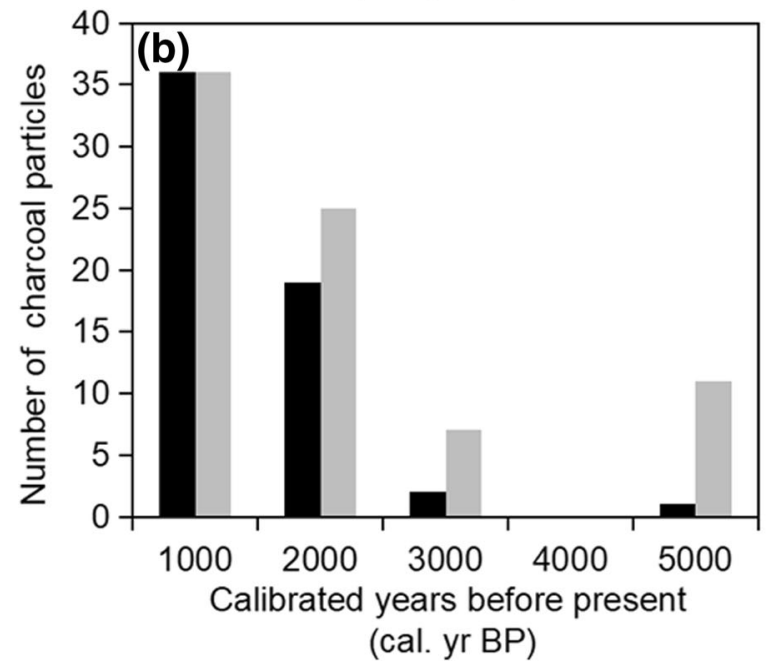

Fig. 4 Number of dated and corrected charcoal fragments as a function of (a) 200-year age classes in the northeastern subtropical dry forest and (b) 1000-year age classes in the southeastern subtropical dry forest in Puerto Rico, USA. The radiocarbon ages of 20 charcoal samples from the northeastern subtropical dry forest were determined by AMS (Accelerator MassSpectrometry) in August and November 2016 at the Earth System Science Department, University of California, Irvine, USA; and the radiocarbon ages of 58 charcoal samples from the southeastern subtropical dry forest were determined by AMS in July and August 2015 at the Lawrence Livermore National Laboratory, California, USA

$\Delta^{13} \mathrm{C}$ values of the southeastern subtropical dry forest fell within the $\Delta^{13} \mathrm{C}$ values of live branches grown in 2015 (21.42 to $23.58 \%$ ). In the recent $800 \mathrm{yr}$, only $57 \%$ of charcoal $\Delta^{13} \mathrm{C}$ values were lower than $\Delta^{13} \mathrm{C}$ values of branches in 2015, and the other $\Delta^{13} \mathrm{C}$ values were greater than $\Delta^{13} \mathrm{C}$ of branches in 2015 (Fig. 6b).

\section{Discussion}

The radiocarbon age of a charcoal fragment corresponds to the time when the wood that comprises 

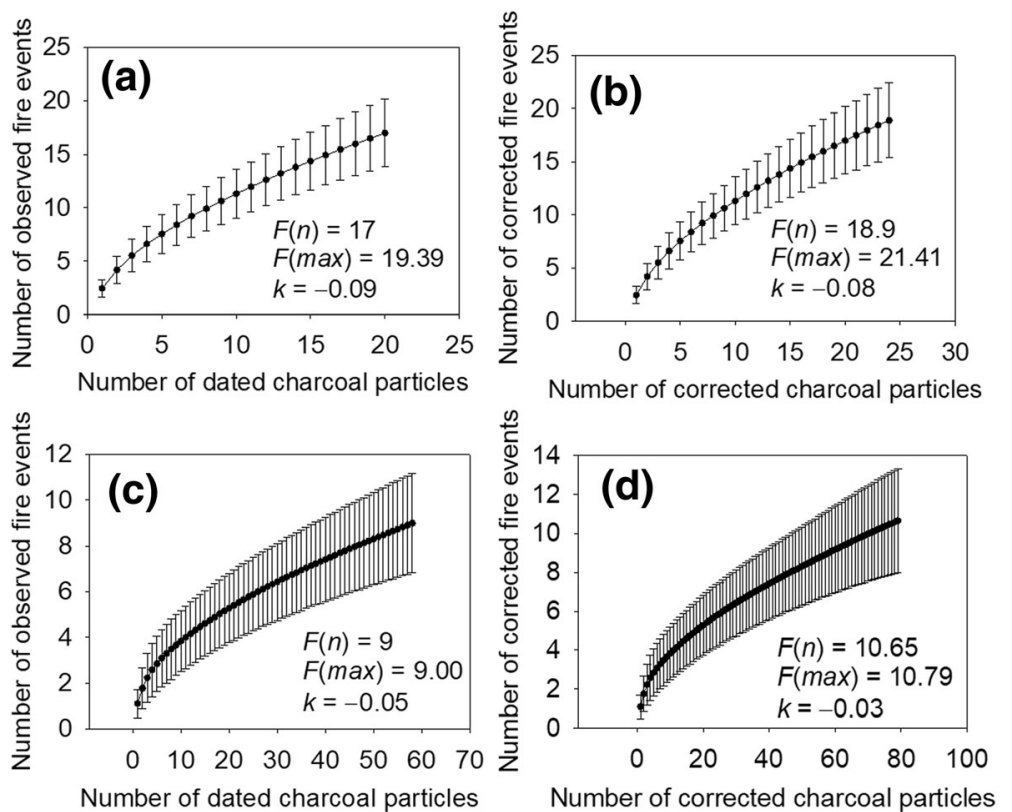

Fig. 5 Accumulated curves of the ( $\mathbf{a}$ and $\mathbf{c}$ ) observed and ( $\mathbf{b}$ and $\mathbf{d}$ ) corrected number of fire events based on dated ${ }^{14} \mathbf{C}$ charcoal fragments before and after correction for charcoal decay, respectively, in the (a and $\mathbf{b}$ ) northeastern and (c and $\mathbf{d}$ ) southeastern subtropical dry forest of Puerto Rico, USA. Charcoal was sampled in December 2015 in the northeastern subtropical dry forest, and in December 2014 in the southeastern subtropical dry forest. Dots $(\cdot)$ indicate the mean number of fire events for the corresponding number of charcoal particles; horizontal bars indicate the $95 \%$ variation range of fire events for the corresponding number of charcoal particles; and lines indicate accumulated curves. The diversity function of EstimateS 9 was used to calculate the observed or estimated fire events in dated or estimated charcoal particles. The $F($ max) index and the constant $k$ were calculated using the equation of exponential regression in Sigmaplot 14.0

charcoal was actually produced and not to the actual age of a fire event (de Lafontaine and Payette 2011). Therefore radiocarbon age may be several centuries older than the actual date of the fire that produced charcoal in most forests (de Lafontaine and Payette 2011). This is "inbuilt age error." The value of inbuilt age error depends on forest stand age structure and rate of wood decay (Gavin 2001, Gavin et al. 2003) and by the prevailing fire regime itself (Higuera et al. 2005). In sites experiencing more frequent fires with short-lived trees and fast decaying wood, the radiocarbon dates of charcoal were regarded as a proxies for actual fire ages (de Lafontaine and Payette 2011). In the northeastern and southeastern subtropical dry forest of Puerto Rico, estimates of mean fire interval were all between 63 and $607 \mathrm{yr}$. Data for tree lifespan in tropical dry forests are broadly lacking. Tree lifespan in some tropical rain forests is between 70 and $138 \mathrm{yr}$ (Swaine et al. 1987). Wood decay turnover time is around 2 to $22 \mathrm{yr}$ in Puerto Rican wet and dry forests (Torres and González 2005, González et al. 2008).

Our estimated charcoal decay rates were $0.0010 \mathrm{yr}^{-1}$ in the northeastern dry forest and $0.0008 \mathrm{yr}^{-1}$ in the southeastern dry forest of Puerto Rico, corresponding to 1000 and $1250 \mathrm{yr}$ of residence time, respectively. The residence time of soil pyrogenic carbon appeared to vary regionally (Ohlson et al. 2009). The average lifespan of charcoal in the subtropical dry forest soils of Puerto Rico is longer than in boreal forest soils $(652 \mathrm{yr}$; Ohlson et al. 2009) and in Russian steppe soils (182 to $541 \mathrm{yr}$; Hammes et al. 2008), but shorter than in Australian savannah soils (1300 to $2600 \mathrm{yr}$; Lehmann et al. 2008). We employed a novel approach to estimate charcoal decay rate by using maximum charcoal size in each age class over time, based on the negative exponential decay function typically found in microbial activity with the assumption that the initial maximum size of charcoal from each age class is relatively invariant over time. Our approach is more rational than Frégeau et al.'s (2015) method of estimating charcoal decay rate using charcoal abundance in each age class over time, which assumed that the numbers of initial charcoal fragments originating from fires were the same for each $200 \mathrm{yr}$ age class. It is well understood that charcoal abundance differs among age classes, not only because charcoal decays, but also due to the fact that fire frequency and intensity vary over time as climate conditions change (Frégeau et al. 2015). Variation of fire frequency and intensity was exactly the purpose of various studies reconstructing paleoclimate and documenting human disturbance (Caffrey and Horn 2014). Our data suggest that charcoal 


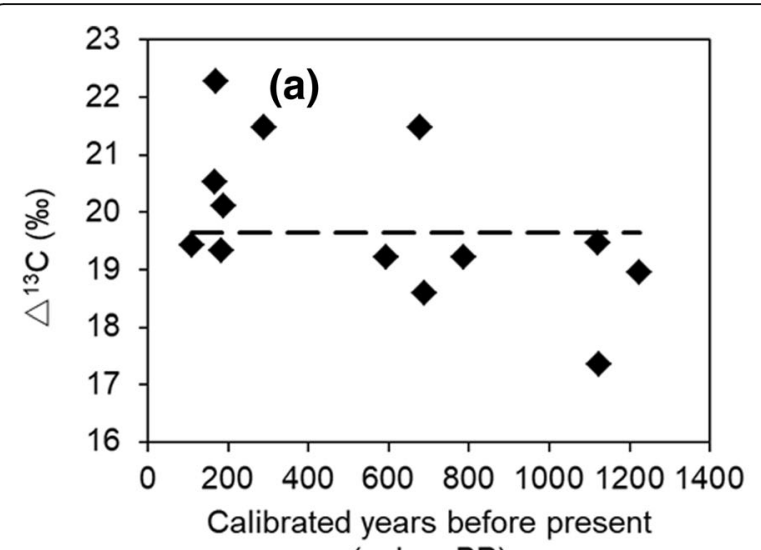

(cal. yr BP)

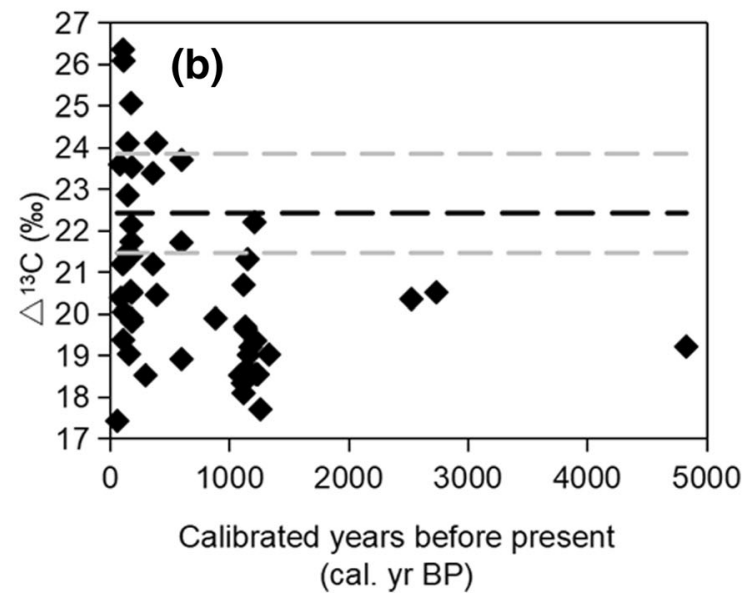

Fig. 6 Time-series of ${ }^{13} \mathrm{C}$ discrimination $\left(\triangle^{13} \mathrm{C}\right)$ in the $(\mathbf{a})$ northeastern and (b) southeastern subtropical dry forest of Puerto Rico, USA. Charcoal was sampled in December 2015 in the northeastern subtropical dry forest, and in December 2014 in the southeastern subtropical dry forest. The black dotted lines represent average $\Delta^{13} \mathrm{C}$ values of (a) wood litter fall in the northeastern subtropical dry forest during the 2015 drought year, and (b) branches collected in Dec 2015 in the southeastern subtropical dry forest. The gray dotted lines represent average values $\pm S D$ of $\triangle^{13} C$ of branches collected in Dec 2015 in the southeastern subtropical dry forest. Diamonds ( represent the time series of $\triangle 13 C$. $\delta 13 C$ values were analyzed at Michigan Technological University in Aug and Dec 2016, and May 2017

decays at a relatively constant rate in the northeastern and southeastern dry forests of Puerto Rico regardless of the substantial difference in their annual mean temperature and precipitation. Our assumption that an invariant maximum size of initial charcoal over age classes relies on the understanding that soil development is extremely slow and most residential soils are aged for millions of years in the tropics (Birkeland et al. 1992); thus, naturally depositional environments, such as soil pore size, drying-rewetting cycles, and erosion and burial processes, are likely little changed for each time interval of 200 to 1000 yr over 5000 years. However, anthropogenic activities may alter naturally depositional environment, thus affecting the estimation of charcoal decay rate using our approach.

Charcoal decay may lead to an underestimation of paleofire events. In this study, we attempted to correct this underestimation by reconstructing initial charcoal sizes with charcoal decay rate, and assumed that the abundance-size distribution of undecayed charcoal did not vary among charcoal age classes. This approach yielded 2 and 1 additional undetected fire events for the northeastern and southeastern dry forests of Puerto Rico, respectively. Similarly, our assumption that invariant undecayed charcoal abundance-size distribution relies on the fact that it takes millions of years for residential soils to develop, and that the depositional environment of soil charcoal varies little over a 1000-year period. Again, soil disturbances and species invasion can violate this assumption.

Our detected and estimated paleofire events were 17 and 21 for the northeastern dry forest, and 9 and 10 for the southeastern dry forest of Puerto Rico, respectively. Both the northeastern and southeastern subtropical dry forests of Puerto Rico showed a noticeable peak of fire activities between 500 and $1400 \mathrm{cal}$ yr BP, suggesting either a dry climate or increased human activity. The paleofires might be ascribed to slash-and-burn agriculture by pre-Columbus native peoples. The beginning of the development of cultigens was around $2600 \mathrm{cal}$ yr BP in Cuba (Peros et al. 2015) and probably followed shortly thereafter in Puerto Rico. Humans settled around Laguna Grande, near the northeastern subtropical dry forest of Puerto Rico, in 2000 cal yr BP, and this settlement might have lead to deforestation by slash-and-burn agriculture in the majority of the watersheds (Lane et al. 2013). On the other hand, the frequent fires around 800 to $1110 \mathrm{cal}$ yr BP in the subtropical dry forests of Puerto Rico were similar to the intense fires that occurred after hurricanes around 800 to $1000 \mathrm{cal} \mathrm{yr} \mathrm{BP}$ on the Gulf of Mexico coast (Liu et al. 2008), in Costa Rica (Horn and Sanford 1992), and in Laguna Alejandro of Dominican Republic (LeBlanc et al. 2017). On occasion, Puerto Rico, Dominican Republic, and the Gulf of Mexico coast have been on the same path of the same hurricanes (e.g., Hurricane Hugo in 1989, Hurricane Georges in 1998, and Hurricanes Irma and Maria in 2017). Thus, the frequent fires around 800 to $1110 \mathrm{cal} \mathrm{yr} \mathrm{BP}$ in the subtropical dry forest of Puerto Rico might also be explained by inferred hurricanes, which directly struck the Gulf of Mexico coast, Costa Rica, and Laguna Alejandro of Dominican around 800 to $1110 \mathrm{cal}$ yr BP. Because canopies open after hurricanes, insolation and wind speed increase under the canopies, leading to drier microclimates with drier litter on the forest floor post hurricane (Myers and van Lear 1998). The lower $\Delta^{13} \mathrm{C}$ value of charcoal fragments of 800 to $1100 \mathrm{cal}$ yr BP from the subtropical dry forest suggested 
a drier microclimate in subtropical dry forest during this period.

One other characteristic of paleofire patterns shared in both the northeastern and southeastern subtropical dry forest of Puerto Rico is that fire frequency decreased after the immigration of Europeans in the last $500 \mathrm{yr}$. When strong trends in biomass burning were inconsistent with climate trends, human activity became clearly evident (Marlon et al. 2013). Humans might have influenced the fire regime by burning during the wetter seasons for agricultural uses, resulting in more controlled, lower intensity fires (Burney 1997). The three fires of the subtropical forests of Puerto Rico that produced higher $\triangle{ }^{13} \mathrm{C}$ values of charcoal fragments during 400 to $180 \mathrm{cal}$ yr BP (Little Ice Age) might be ascribed to human ignitions. Thus, the apparent peak of fire activities between 500 and $1400 \mathrm{cal}$ yr BP might be attributed to the increased human activity or increased drought stress after hurricanes.

Charcoal older than $1300 \mathrm{cal}$ yr BP was not found in the northeastern subtropical dry forest of Puerto Rico, while two charcoal samples dated $2500 \mathrm{cal} \mathrm{yr} \mathrm{BP}$ and one dated around $5000 \mathrm{cal} \mathrm{yr} \mathrm{BP}$ were detected in the southeastern subtropical dry forest of Puerto Rico. This does not necessarily indicate that fires did not occur before $1300 \mathrm{cal} \mathrm{yr} \mathrm{BP}$ in the northeastern subtropical dry forest. Instead, it suggests that charcoal older than 1300 yr was decayed below our minimum detectable weight of $1.4 \mathrm{mg}$ in the northeastern subtropical dry forest. Because the average turnover time of charcoal in these two subtropical dry forests of Puerto Rico is similar, between 1000 to $1250 \mathrm{yr}$, these three charcoal particles older than 2500 yr might have broken off of bigger charcoal particles that were in the soil after the paleofire in the southeastern dry forest. In fact, the largest charcoal sample weighed $178.1 \mathrm{mg}\left({ }^{14} \mathrm{C}\right.$ age $\left.=190 \pm 30 \mathrm{yr}\right)$, from the southeastern dry forest, which was more than 6-fold more than the $27.4 \mathrm{mg}\left({ }^{14} \mathrm{C}\right.$ age $\left.=235 \pm 20 \mathrm{yr}\right)$ sample from the northeastern dry forest.

The time period (4822 to $4854 \mathrm{cal} \mathrm{yr} \mathrm{BP)} \mathrm{for} \mathrm{the} \mathrm{oldest}$ fire at our study site is in line with the $\sim 5000 \mathrm{cal}$ yr BP paleofire at Laguna Tortuguero, Puerto Rico, which was regarded as evidence of the onset of human disturbance on the landscape. Thus, the 4822 to $4854 \mathrm{cal}$ yr BP fire in the southeastern subtropical dry forest of Puerto Rico was most likely evidence of the settlement of native peoples that predates archeological evidence (Burney et al. 1994), although it could also have been a natural fire. Neotropical forests rarely ignite from natural causes (Kauffman and Uhl 1990) because of the high silica content of the leaves and leaf litter (Ter Welle 1976, Mak 1988). The probability of natural fire in neotropical forest can increase, of course, when invasive plants colonize the understory (Brooks et al. 2004), or when human populations deliberately cut and burn theses forests (Bush et al. 2008). Puerto Rico is thought to have been initially occupied by native peoples about $4713 \mathrm{cal} \mathrm{yr} \mathrm{BP,}$ originating from Maruca $\left(17.99^{\circ} \mathrm{N}, 66.62^{\circ} \mathrm{W}\right.$; Rivera-Collazo et al. 2015). Our finding of the 4822 to $4854 \mathrm{cal}$ yr BP fire in the southeastern subtropical dry forest of Puerto Rico may record an indication of an earlier colonization date for Puerto Rico.

\section{Conclusions}

The decay rate of soil charcoal in the subtropical dry forests of Puerto Rico was 0.0008 to $0.0010 \mathrm{yr}^{-1}$. We estimate that one to two fire events were undetected due to charcoal decay in the subtropical forests of Puerto Rico in the Late Holocene. Our soil macrocharcoal analysis revealed that 21 fire events occurred over the last $1300 \mathrm{yr}$ in the northeastern subtropical dry forest of Puerto Rico, and 10 fire events occurred over the last $4900 \mathrm{yr}$ in the southeastern subtropical dry forest of Puerto Rico. The 4822 to $4854 \mathrm{cal}$ yr BP fire in the southeastern subtropical dry forest of Puerto Rico could have been a natural fire or, more likely, was an indication of the initial occupation of native peoples to this island. Peak fire events occurred during 500 to $1400 \mathrm{cal}$ yr BP in the subtropical dry forest of Puerto Rico. The paleofire peak of the subtropical dry forest of Puerto Rico may be ascribed to agricultural activities of pre-Columbus dwellers and inferred hurricanes that directly struck the Gulf of Mexico coast, Costa Rica, and Laguna Alejandro of Dominican around 800 to $1110 \mathrm{cal}$ yr BP. Fire frequency of the subtropical dry forest in Puerto Rico decreased after the immigration of Europeans in the last 500 years. Future studies should examine the temporal change in paleo-vegetation and anthropology to improve the understanding of the causes of paleofire, and to evaluate fire-mediated changes in vegetation and climate in the subtropical dry forests of Puerto Rico.

\section{Additional file}

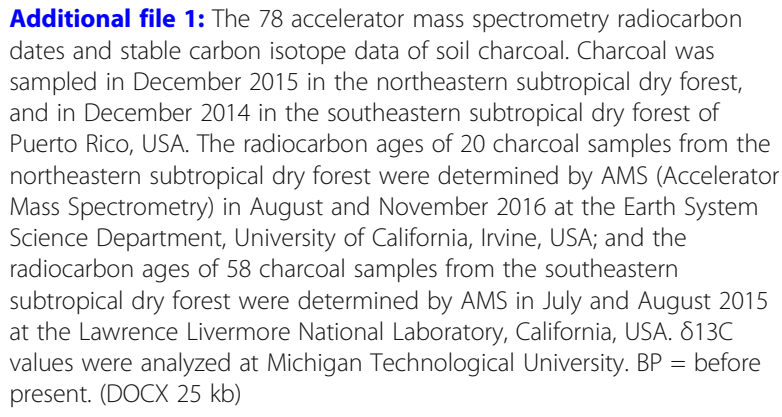

Additional file 1: The 78 accelerator mass spectrometry radiocarbon dates and stable carbon isotope data of soil charcoal. Charcoal was sampled in December 2015 in the northeastern subtropical dry forest, and in December 2014 in the southeastern subtropical dry forest of Puerto Rico, USA. The radiocarbon ages of 20 charcoal samples from the northeastern subtropical dry forest were determined by AMS (Accelerator Mass Spectrometry) in August and November 2016 at the Earth System Science Department, University of California, Irvine, USA; and the radiocarbon ages of 58 charcoal samples from the southeastern subtropical dry forest were determined by AMS in July and August 2015 at the Lawrence Livermore National Laboratory, California, USA. $813 \mathrm{C}$ values were analyzed at Michigan Technological University. $\mathrm{BP}=$ before present. (DOCX $25 \mathrm{~kb}$ )

\section{Acknowledgements}

We are most grateful to H. Robles, M. Rivera, and I. Vicens for field assistance, and to Dr. A. Lugo for valuable comments. All research at the USDA Forest Service International Institute of Tropical Forestry was done in collaboration with the University of Puerto Rico. 


\section{Funding}

This study was financially supported by a cooperative project between the International Institute of Tropical Forestry, USDA-Forest Service, and the University of Puerto Rico (14-JV-11120101-018). G. González was supported by the Luquillo Critical Zone Observatory (National Science Foundation grant EAR-1331841) and the Luquillo Long-Term Ecological Research Site (National Science Foundation grant DEB-1239764).

\section{Availability of data and materials}

The datasets used or analyzed during the current study are available from the corresponding author on reasonable request.

\section{Authors' contributions}

$W H, X L, G G$ and $X Z$ designed the experiments. WH and $X L$ performed the experiments and analyzed the data. $\mathrm{WH}, \mathrm{XL}, \mathrm{GG}$ and $\mathrm{XZ}$ contributed to writing the paper. All authors reviewed the manuscript. All authors read and approved the final manuscript.

\section{Ethics approval and consent to participate}

Not applicable.

\section{Consent for publication}

Not applicable.

\section{Competing interests}

The authors declare that they have no competing interests.

\section{Publisher's Note}

Springer Nature remains neutral with regard to jurisdictional claims in published maps and institutional affiliations.

\section{Author details}

1Department of Environmental Sciences, College of Natural Sciences, University of Puerto Rico, P.O. Box 70377, San Juan, PR 00936-8377, USA. ${ }^{2}$ International Institute of Tropical Forestry, USDA Forest Service, Jardín Botánico Sur, 1201 Calle Ceiba, Río Piedras, PR 00926-1119, USA. ${ }^{3}$ College of Biology and the Environment, Nanjing Forestry University, 159 Longpan Road, Nanjing 210037, Jiangsu, China.

Received: 30 August 2018 Accepted: 5 March 2019

Published online: 30 April 2019

\section{References}

Adámek, M., P. Bobek, V. Hadincová, J. Wild, and M. Kopecký. 2015. Forest fires within a temperate landscape: a decadal and millennial perspective from a sandstone region in central Europe. Forest Ecology and Management 336: 81 90. https://doi.org/10.1016/j.foreco.2014.10.014

Barry, R.G., and R.J. Chorley. 2010. Atmosphere, weather and climate. Routledge, London, England, United Kingdom. https://doi.org/10.4324/9780203871027

Birkeland, P., I. Martini, and W. Chesworth. 1992. Quaternary soil chronosequences in various environments - extremely arid to humid tropical. Pages 261-281 in: I.P. Martini and W. Chesworth, editors. Weathering, soils and paleosols. Elsevier, Amsterdam, The Netherlands. https://doi.org/10.1016/B978-0-44489198-3.50016-7

Brooks, M.L., C.M. D'Antonio, D.M. Richardson, J.B. Grace, J.E. Keeley, J.M. DiTomaso, R.J. Hobbs, M. Pellant, and D. Pyke. 2004. Effects of invasive alien plants on fire regimes. BioScience 54: 677-688. https://academic.oup.com/ bioscience/article/54/7/677/223532

Burney, D.A. 1997. Tropical islands as paleoecological laboratories: gauging the consequences of human arrival. Human Ecology 25: 437-457. https://doi.org/ 10.1023/A:1021823610090

Burney, D.A., L.P. Burney, and R.D.E. MacPhee. 1994. Holocene charcoal stratigraphy from Laguna Tortuguero, Puerto Rico, and the timing of human arrival on the island. Journal of Archaeological Science 21: 273-281. https:// doi.org/10.1006/jasc.1994.1027

Bush, M.B., A.M. Alfonso-Reynolds, D.H. Urrego, B.G. Valencia, Y.A. Correa-Metrio, M. Zimmerman, M.R. Silman, and J.C. Svenning. 2015. Fire and climate: contrasting pressures on tropical Andean timberline species. Journal of Biogeography 42: 938-950. https://doi.org/10.1111/jbi.12470

Bush, M.B., M. Silman, C. McMichael, and S. Saatchi. 2008. Fire, climate change and biodiversity in Amazonia: a Late-Holocene perspective. Philosophical
Transactions of the Royal Society B 363: 1795-1802. https://doi.org/10.1098/ rstb.2007.0014

Caffrey, M.A., and S.P. Horn. 2014. Long-term fire trends in Hispaniola and Puerto Rico from sedimentary charcoal: a comparison of three records. The Professional Geographer 67: 229-241. https://doi.org/10.1080/ 00330124.2014 .922017

Cochrane, M.A., and M.D. Schulze. 1999. Fire as a recurrent event in tropical forests of the eastern Amazon: effects on forest structure, biomass, and species composition. Biotropica 31: 2-16. https://doi.org/10.2307/2663955

Colwell, R.K., and J.E. Elsensohn. 2014. EstimateS turns 20: statistical estimation of species richness and shared species from samples, with non-parametric extrapolation. Ecography 37: 609-613.

Crausbay, S.D., P.H. Martin, and E.F. Kelly. 2015. Tropical montane vegetation dynamics near the upper cloud belt strongly associated with a shifting ITCZ and fire. Journal of Ecology 103: 891-903. https://doi.org/10.1111/ 1365-2745.12423

de Lafontaine, G., and S. Payette. 2011. Long-term fire and forest history of subalpine balsam fir (Abies balsamea) and white spruce (Picea glauca) stands in eastern Canada inferred from soil charcoal analysis. Holocene 22: 191-201. https://doi.org/10.1177/0959683611414931

Ewel, J.J., and J.L. Whitmore. 1973. The ecological life zones of Puerto Rico and the US Virgin Islands. https://www.fs.usda.gov/treesearch/pubs/5551 Accessed 15 Nov 2015.

Fiorentino, G., J.P. Ferrio, A. Bogaard, J.L. Araus, and S. Riehl. 2014. Stable isotopes in archaeobotanical research. Vegetation History and Archaeobotany 24: 215 227. https://doi.org/10.1007/s00334-014-0492-9

Foster, D.R., M. Fluet, and E. Boose. 1999. Human or natural disturbance: landscape-scale dynamics of the tropical forests of Puerto Rico. Ecological Applications 9: 555-572. https://doi.org/10.2307/2641144

Frégeau, M., S. Payette, and P. Grondin. 2015. Fire history of the central boreal forest in eastern North America reveals stability since the mid-Holocene. Holocene 25: 1912-1922. https://doi.org/10.1177/0959683615591361

Gavin, D.G. 2001. Estimation of inbuilt age in radiocarbon ages of soil charcoal for fire history studies. Radiocarbon 43: 27-44. https://doi.org/10.1017/ S003382220003160X

Gavin, D.G., L.B. Brubaker, and K.P. Lertzman. 2003. Holocene fire history of a coastal temperate rain forest based on soil charcoal radiocarbon dates. Ecology 84: 186 201. https://esajournals.onlinelibrary.wiley.com/doi/abs/10.1890/0012 9658(2003)084\%5B0186:HFHOAC\%5D2.0.CO\%3B2

González, G., W.A. Gould, A.T. Hudak, and T.N. Hollingsworth. 2008. Decay of aspen (Populus tremuloides Michx.) wood in moist and dry boreal, temperate, and tropical forest fragments. AMBIO: A Journal of the Human Enviornment 37: 588-597. https://doi.org/10.1579/0044-7447-37.7.588

Gould, W., G. González, and R.G. Carrero. 2006. Structure and composition of vegetation along an elevational gradient in Puerto Rico. Journal of Vegetation Science 17: 653-664. https://doi.org/10.1111/j.1654-1103.2006.tb02489.x

Guariguata, M.R. 1990. Landslide disturbance and forest regeneration in the upper Luquillo Mountains of Puerto Rico. Journal of Ecology 78: 814-832. https://doi.org/10.2307/2260901

Hall, G., S. Woodborne, and M. Scholes. 2008. Stable carbon isotope ratios from archaeological charcoal as palaeoenvironmental indicators. Chemical Geology 247: 384-400. https://doi.org/10.1016/j.chemgeo.2007.11.001

Hammes, K. M.S. Torn, A.G. Lapenas, and M.W. Schmidt. 2008. Centennial black carbon turnover observed in a Russian steppe soil. Biogeosciences 5: 13391350. https://doi.org/10.5194/bg-5-1339-2008

Higuera, P.E., D.G. Sprugel, and L.B. Brubaker. 2005. Reconstructing fire regimes with charcoal from small-hollow sediments: a calibration with tree-ring records of fire. Holocene 15: 238-251. https://doi.org/10.1191/0959683605hl789rp

Hjerpe, J., H. Hedenås, and T. Elmqvist. 2001. Tropical rain forest recovery from cyclone damage and fire in Samoa. Biotropica 33: 249-259. https://doi.org/10. 1111/j.1744-7429.2001.tb00176.x

Horn, S.P., and R.L. Sanford Jr. 1992. Holocene fires in Costa Rica. Biotropica 24: 354-361. https://doi.org/10.2307/2388605

Hubau, W., J. Van den Bulcke, J. Van Acker, and H. Beeckman. 2015. Charcoalinferred Holocene fire and vegetation history linked to drought periods in the Democratic Republic of Congo. Global Change Biology 21: 2296-2308. https://doi.org/10.1111/gcb.12844

Inoue, J., R. Okunaka, and T. Kawano. 2016. The relationship between past vegetation type and fire frequency in western Japan inferred from phytolith and charcoal records in cumulative soils. Quaternary International 397: 513522. https://doi.org/10.1016/j.quaint.2015.02.039 
Kauffman, J., and C. Uhl. 1990. Interactions of anthropogenic activities, fire, and rain forests in the Amazon Basin. Pages 117-134 in: J.G. Goldammer, editor. Fire in the tropical biota. Springer, Berlin, Heidelberg, Germany. https://doi. org/10.1007/978-3-642-75395-4_8

Lane, C.S., J.J. Clark, A. Knudsen, and J. McFarlin. 2013. Late-Holocene paleoenvironmental history of bioluminescent Laguna Grande, Puerto Rico. Palaeogeography, Palaeoclimatology, Paleoecology 369: 99-113. https://doi. org/10.1016/j.palaeo.2012.10.007

LeBlanc, A.R., L.M. Kennedy, K. Liu, and C.S. Lane. 2017. Linking hurricane landfalls, precipitation variability, fires, and vegetation response over the past millennium from analysis of coastal lagoon sediments, southwestern Dominican Republic. Journal of Paleolimnology 58: 135-150. https://doi.org/ 10.1007/s10933-017-9965-z

Lehmann, J., J. Skjemstad, S. Sohi, J. Carter, M. Barson, P. Falloon, K. Coleman, P. Woodbury, and E. Krull. 2008. Australian climate-carbon cycle feedback reduced by soil black carbon. Nature Geoscience 1: 832-835. https://doi.org/ $10.1038 /$ ngeo358

Liu, K., H. Lu, and C. Shen. 2008. A 1200-year proxy record of hurricanes and fires from the Gulf of Mexico coast: testing the hypothesis of hurricane-fire interactions. Quaternary Research 69: 29-41. https://doi.org/10.1016/j.yqres. 2007.10.011

Mak, E.H. 1988. Measuring foliar flammability with the limiting oxygen index method. Forest Science 34: 523-529.

Marlon, J.R., P.J. Bartlein, A.L. Daniau, S.P. Harrsion, S.Y. Maezumi, M.J. Power, W. Tinner, and B. Vanniere. 2013. Global biomass burning: a synthesis and review of Holocene paleofire records and their controls. Quaternary Science Reviews 65: 5-25. https://doi.org/10.1016/j.quascirev.2012.11.029

McMichael, C., A. Correa-Metrio, and M. Bush. 2012. Pre-Columbian fire regimes in lowland tropical rainforests of southeastern Peru. Palaeogeography, Palaeoclimatology, Paleoecology 342: 73-83. https://doi.org/10.1016/j.palaeo. 2012.05.004

Moskal-del Hoyo, M., M. Wachowiak, and R. Blanchette. 2010. Preservation of fungi in archaeological charcoal. Journal of Archaeological Science 37: 21062116. https://doi.org/10.1016/j.jas.2010.02.007

Mote, T.L., C.A. Ramseyer, and P.W. Miller. 2017. The Saharan Air Layer as an early rainfall season suppressant in the eastern Caribbean: the 2015 Puerto Rico drought. Journal of Geophysical Research, Atmospheres 122: 10,966-10,982. https://doi.org/10.1002/2017JD026911

Muñoz, M.A., W.I. Lugo, C. Santiago, M. Matos, S. Ríos, and J. Lugo. 2017. Taxonomic classification of the soils of Puerto Rico. https://dire.uprm.edu/ handle/20.500.11801/817 Accessed 23 Jan 2018.

Myers, R.K., and D.H. van Lear. 1998. Hurricane-fire interactions in coastal forests of the South: a review and hypothesis. Forest Ecology and Management 103 265-276. https://doi.org/10.1016/S0378-1127(97)00223-5

Ohlson, M., B. Dahlberg, T. Økland, K.J. Brown, and R. Halvorsen. 2009. The charcoal carbon pool in boreal forest soils. Nature Geoscience 2: 692-695. https://doi.org/10.1038/ngeo617

Pascarella, J.B., A.T. Mitchell, and J.K. Zimmerman. 2004. Short-term response of secondary forests to hurricane disturbance in Puerto Rico, USA. Forest Ecology and Management 199: 379-393. https://doi.org/10.1016/j.foreco. 2004.05.041

Payette, S., A. Delwaide, A. Schaffhauser, and G. Magnan. 2012. Calculating longterm fire frequency at the stand scale from charcoal data. Ecosphere 3(7): 59. https://doi.org/10.1890/ES12-00026.1

Payette, S., V. Pilon, P.L. Couillard, and J. Laflamme. 2017. Fire history of Appalachian forests of the Lower St-Lawrence region (southern Quebec). Forests 8: 120. https://doi.org/10.3390/f8040120

Peros, M., B. Gregory, F. Matos, E. Reinhardt, and J. Desloges. 2015. Late-Holocene record of lagoon evolution, climate change, and hurricane activity from southeastern Cuba. Holocene 25: 1483-1497. https://doi.org/10.1177/ 0959683615585844

Ping, C.L., G.J. Michaelson, C.A. Stiles, and G. González. 2013. Soil characteristics, carbon stores, and nutrient distribution in eight forest types along an elevation gradient, eastern Puerto Rico. Ecological Bulletins 54: 67-86.

Rivera-Collazo, I., A. Winter, D. Scholz, A. Mangini, T. Miller, Y. Kushnir, and D. Black. 2015. Human adaptation strategies to abrupt climate change in Puerto Rico ca. 3.5 ka. The Holocene 25: 627-640. https://doi.org/10.1177/ 0959683614565951

Slater, C., T. Preston, and L.T. Weaver. 2001. Stable isotopes and the international system of units. Rapid Communications in Mass Spectrometry 15: 1270-1273. https://doi.org/10.1002/rcm.328
Swaine, M., D. Lieberman, and F.E. Putz. 1987. The dynamics of tree populations in tropical forest: a review. Journal of Tropical Ecology 3: 359-366

Ter Welle, B.J.H. 1976. Silica grains in woody plants of the Neotropics, especially Surinam. Pages 107-142 in: P. Baas, A.J. Bolton, and D.M. Catling, editors. Wood structure in biological and technological research. Leiden botanical series 3. Leiden University Press, Leiden, The Netherlands.

Tieszen, L.L., and T. Fagre. 1993. Carbon isotopic variability in modern and archaeological maize. Journal of Archaeological Science 20: 25-40. https://doi. org/10.1006/jasc.1993.1002

Tilston, E.L., P. Ascough, M.H. Garnett, and M.I. Bird. 2016. Quantifying charcoal degradation and negative priming of soil organic matter with a ${ }^{14} \mathrm{C}$-dead tracer. Radiocarbon 58: 905-919. https://doi.org/10.1017/RDC.2016.45

Torres, J.A., and G. González. 2005. Wood decomposition of Cyrilla racemiflora (Cyrillaceae) in Puerto Rican dry and wet forests: a 13-year case study. Biotropica 37: 452-456. https://doi.org/10.1111/j.1744-7429.2005.00059.x

Tovar, C., E. Breman, T. Brncic, D.J. Harris, R. Bailey, and K.J. Willis. 2014. Influence of 1100 years of burning on the central African rainforest. Ecography 37: 1139-1148. https://doi.org/10.1111/ecog.00697

USDA Soil Conservation Service. 1977. Soil survey of Humacao area of eastern Puerto Rico. https://www.nrcs.usda.gov/Internet/FSE_MANUSCRIPTS/puerto_ rico/PR689/0/Humacao.pdf Accessed 10 July 2015.

Waide, R.B., and A.E. Lugo. 1992. A research perspective on disturbance and recovery of a tropical montane forest. Pages 173-190 in: J.G. Goldammer, editor. Tropical forests in transition. Birkhäuser, Basel, Switzerland. https:// doi.org/10.1007/978-3-0348-7256-0_12

Zimmerman, J.K., E.M. Everham III, R.B. Waide, D.J. Lodge, C.M. Taylor, and N.V. Brokaw. 1994. Responses of tree species to hurricane winds in subtropical wet forest in Puerto Rico: implications for tropical tree life histories. Journal of Ecology 82: 911-922. https://doi.org/10.2307/2261454

\section{Submit your manuscript to a SpringerOpen ${ }^{\circ}$ journal and benefit from:}

- Convenient online submission

- Rigorous peer review

- Open access: articles freely available online

- High visibility within the field

- Retaining the copyright to your article

Submit your next manuscript at $\boldsymbol{\nabla}$ springeropen.com 